fiinish and appearance, convenience of being out of the way when not in use and its adaptability for plaster corset work, which is not the case with the Lorenz instrument. And last, and most important, is its transportability from plaster rooms to wards, dressing rooms, $x$-ray room or private homes.

This apparatus may be placed on an ordinary roller table, and the patient lifted from the bed into position and partially extended, which gives immediate relief from the pain in nearly all bone lesions. Then he is wheeled to the $x$-ray room, and the proper extension is applied under fluoroscopic observation; then to the plaster room and the cast is applied, and, if necessary, back to the ward until the cast is hard, giving the patient pain but once. In private practice its advantages need not be mentioned, as they are quite apparent.

This device complete can be made by any good instrument-maker or by a good machinist, and costs about $\$ 70$. This includes the best materials and all metal parts nickeled. There are no parts to wear or break, and when well made the apparatus is exceedingly handsome and forms an important adjunct to any surgeon's armamentarium.

\section{AN ILLUMINATED EYE SPUD AND KNIFE NEEDLE.}

\section{ROBERT L. CARSON, M.D.} ROCHESTER, N. $\mathbf{Y}$.

'To remove a foreign body from the cornea with dexterity and without undue injury, particularly where the ebject is small, and difficult to see, one often requires three hands, one hand to hold the lids, another for the eye spud, and a third to condense the light on the eye. Every physician knows how difficult and awkward it is to hold a patient's lids and with the same hand try to condense the light on the cornea.

With the end in view of rendering this common opers.tion easy of performance, I devised an instrument which does away with the need of an extra hand to condense the light on the cornea. Briefly, this is an instrument which combines the spud and light, consisting, as originally devised, of a handle about five inches in length, through which run the wires to a tiny incan-

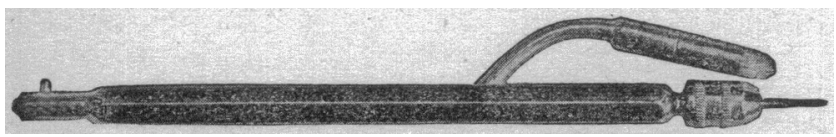

Author's combined illuminated eye spud and knife needle.

descent condensing lamp at its end. A short distance from the end of the handle is a clamp into which is fastened a spud of sufficient length, and bent at such an angle as to bring its tip into the center of the circle of light thrown by the lamp.

Such an instrument was made in accordance with my idea and on my suggestion, but the manufacturers have since modified and somewhat improved it by reversing the position of the light and spud. As now made the spud is attached directly at the end of the handle, the light being thrown on the field at an angle through an arm thrown out from the side of the handle. This makes a somewhat better instrument by lessening the shadow thrown by the spud. The same instrument, with a knife needle in place of a spud, is admirably adapted to the performance of the operation for secondary cataract, where the illumination is of so great importance.

\section{Special Article}

VIENNA AFTER THIRTY-FOUR YEARS.

WILIIAM OSLER, M.D.

Regius Professor of Medicine at the University of Oxford. OXFORD, ENGLAND.

I spent the first four months of 1874 here. I came from Derlin with Hutchinson, an Edinburgh man (Sir Charles F., who has recently died), and we lived together near the Allgemeines Krankenhaus. As illustrating the total blotting out of certain memories, particularly for places, I may mention that strolling to-day up the Alserstrasse $I$ could not recall the street, much less the house, where we had lived for the four months. I found my way readily enough to the Riedhoff, where we were in the habit of dining, and where $I$ first met my old friends, Fred Shattuck, E. H. Bradford, E. G. Cutler and Sabine of Boston. An extraordinary development has taken place in the city within thirty years, and I scarcely recognized the Ringstrasse. Then, only the foundations of the new university buildings and of the Rathaus had been begun. Now these, with the parliament house, the courts of justice, the twin museums of art and natural history and the new Bourg Theater, form a group of buildings unrivaled in any city. THE GERMAN CONGRESS FOR INTERNAL MEDICINE.

The primary object of my visit was to attend the Congress fiir Innere Medizin, and I had the pleasure of having with me my old student and friend, Dr. Joseph $H$. Pratt of Boston. We reached Vienna in time for the preliminary Sunday evening social gathering in the Kursalon of the City Park. Here we found a greeting in true German fashion and a hearty welcome from the president, Professor Müller of Munich. The work of the congress began at sharp 9:30 on Monday morning with a discussion on the "Relation of the Diseases of the Female Generative Organs to Internal Maladies." Unfortunately, the large University Hall, in which the meeting was held, was most unsuitable. Though seated not very far away, Professor Rosthorn's remarks were almost inaudible. It is a miserable mistake in introducing a discussion on any subject to speak for more than half an hour, but to continue for an hour and a quarter is too much for human endurance, and great many did not wait for Profêssor Lenhartz's discussion of the problem from the standpoint of internal medicine. Nothing new was brought out, and so far as I could gather, Professor Rosthorn took much the same ground as Clifford Allbutt in his well-known Goulstonian lectures dealing with the intimate relationship through the sympathetic nervous system of the generative functions with those of the other organs.

Quite an animated discussion followed, in which Stintzing, Turban, Klemperer and others took part. Dr. Singer read a most interesting paper on "Intestinal Diseases in the Climacteric," calling attention particularly to frequent hemorrhages which he had known to arouse suspicion of malignant disease.

In the evening the city fathers gave a magnificent banquet to the congress in the superb hall of the Rathaus. At three long tables were seated some 600 guests.

On Tuesday morning Professor Neisser of Breslau opened the discussion on the "Present Position of the Pathology and Therapy of Syphilis." This was a splendid address, delivered without notes, in a good clear voice, and the subject matter arranged in a most orderly manner. He dealt particularly with the three points brought out by recent investigationsSchaudinn's discovery of the spirochete, the discovery of Metchnikoff that apes could be infected, and the discovery of Schaudinn that the fluids of infected persons reacted specifically. He dealt very fully with his own experimental work in Java, much of which has appeared, but it was particularly interesting to hear the relation of the extraordinary influence of atoxyl on the infected animals. It acts as a specific and prevents the development of the spirochetes, so that if given soon the disease could be completely stopped, and later the animal reinfected. Neisser was followed by Professor Wassermann, who described with great clearness his studies on the specific reaction. We have now apparently a diagnostic means by which the presence of the disease mav be definitelv deter- 
mined at a very early stage. As the reaction may be present before secondary symptoms appear, it will have a very important influence in early treatment. The general expression of opinion is very favorable to the method. Professor Finger spoke of it to me in the warmest terms. It persists after all clinical symptoms have disappeared, and a positive response in locomotor ataxia and in general paralysis clinches the question of the true syphilitic nature of these maladies. Both Neisser's and Wassermann's addresses were models.

One of the most important communications of the congress was from von Noorden's clinic. Two of his assistants have been carrying on researches on the "Mutual Relations of the Pancreas and Thyroid." For many years von Noorden has had the idea that there was some important mutual influence between these two organs. The remarkable fact comes out that in animals from which the thyroid gland has been removed it is impossible to produce diabetes by or the known methods, not even by the Claude Bernard punctures the medulta.

Of the third day of the congress I saw but little. Professor Schmidt of Halle introduced a discussion on "New Clinical Methods of Investigating the Functions of the Intestine," in which he went over his recent work very fully, most of which has already been referred to in THE JournaL.

\section{DINNER TO THE CONGRESS.}

At the dinner of the congress His threw out the interesting suggestion (apropos of the presence of Griinbaum and TreveIyan from Leeds, Pratt from Boston, Barr from Portland, Ore., and myself), that the time had come to have an International Congress for Internal Medicine. The physiologists, the laryngologists, the alienists and others have such gatherings, and there now exist in France, Germany and Italy, England and the United States special societies devoted to internal medicine. A congress once in four or five years would be most helpful. We should get to know each other and be able to appreciate better the work done in different countries. Professor Schultze of Bonn gave his usual humorous sketch of the proceedings of the congress, which was greatly appreciated. A ripple of excitement spread around the tables when it was noticed that the places in the orchestra of the pianist and the first violin had been taken by von Neusser and His. The members gathered around the elevated gallery and the distinguished artists were greeted with loud applause and had a vigorous encore.

THE VIENNA LIBRARIES.

Prof. Max Neuburger, whose name is so well known in association with Pagel as editor of the "Handbuch der Geschichte der Medizin," very kindly arranged to show me the points of interest in the Vienna libraries. I may mention, by the way, that Professor Neuburger's new work on the "History of Medicine," of which one volume has appeared, is being translated and will be published from the Oxford University Press. He expects to have Volume II completed this year, and we hope to issue the English edition complete in one volume within the next fifteen months. I was greatly interested to see the new home of the Wiener medizinische Gesellschaft, built under the presidency of Billroth, which combines features of a library, a chb and meeting place. The auditorium is exceptionally well arranged with seats for 300 , and there is a large gallery. The library now numbers more than 40,000 volumes and is very rich in current periodicals. The university library is one of the largest in the city, and the arrangement in it for the accommodation of the medical students seems to be excellent. At the time of our visit the section of the reading room assigned to them was nearly full. A room has been set aside in connection with the medical faculty for the collection of all the literature relating to the history of the school, for the collection of the works of all the famous old men connected with it, and a repository for pictures and instruments, etc., the whole to form a collection illustrating the evolution of the history of the medical department of the university. This example could very well be followed in all of our medical schools. It has been done to some extent at the University of Pennsylvania, as William Pepper III. has already made large collections for this purpose.
The Hofbibliothek is unusually rich in manuscripts and early printed books. I was anxious to see the cepy of "Christianismi Restitutio" of Michael Servetus, 1553, in which for the first time the lesser circulation is described. This is one of the only two known copies in existence. The entire edition was confiscated, and the author, at the time a practitioner in the little town of Vienne, near Lyons, fled for his life to Geneva. Here his heterodoxy was quite as obnoxious to Calvin, into whose hands he fell, and he was burnt at the stake in the same year. The "Restitutio" is one of the rare books of the world. Only two of the 1,000 copies known to have been printed have survived. The one in the Bibliotheque Nationale originally belonged to Dr. Mead, and the history is fully given in an appendix in Willis' work, "Servetus and Calvin." "The Vienna copy is in excellent preservation, beautifully bound, and states on the title page that it came from the library of a Transylvanian gentleman living in London. It fell into the hands of Count de Izek, who presented it to the emperor of Austria. It is a thick, small octavo of about 700 pages. The first one to give credit to Servetus for his discovery of the lesser circulation was Wotton, whose "Reflections Upon Learning, Ancient and Modern," 1694, is a most interesting book, for an introduction to which I have long been grateful to $\mathrm{my}$ friend, Dr. Norman Moore. The other work that I was most anxious to see was the famous manuscript of Dioscorides, prepared at the end of the fifth century for Julia, daughter of the Emperor Flavius. It is one of the great treasures of the library. Now to us in the West only a name, Dioscorides, an army surgeon of the time of Nero, fills a great place in the history of medicine, and is still an oracle in the Orient. He was not only a great botanist, but he was one of the first scientific students of pharmacology. Scores of fine editions of his work, with commentaries, were issued in the fifteenth and sixteenth centuries. Two years ago this Vienna manuscript was reproduced in fac simile at Leyden. Though very expensive, the two volumes costing $\$ 150$, it is a work which all the larger libraries should get, and it is just the sort of present librarians should make our wealthy consultants feel it a privilege to give.

\section{THE HOSPITALS.}

I was surprised to hear Professor Miiller say that he thought in hospital architecture Vienna led the world, and that there was here a group of architects who were adepts in all matters relating to hospital construction. I have come to his conclusion, on what may appear to be very hastily acquired data. It is not often that in the same day and in the same institution one passes from eighteenth to twentieth century conditions. Dr. Koessler took us to the old medical clinic, now in charge of von Neusser, where I found the old wards very much the same as I remember them in 1874. Except in minor details, not only Oppolzer and Skoda, but probably also Peter Frank and de Haen could return to the Allgemeines Kranken. haus and not be surprised by any very unfamiliar sights. The is the same extraordinary wealth of clinical material. I must say it was a surprise to see-the old type of nurse; not, of course, that she is necessarily either unintelligent or inattentive. Indeed, as we passed a bed in which there was a new patient whom the junior assistant had not seen, he turned to one of the nurses, who in reply to his question said, "Yes, Herr - says she has mitral stenosis and insuf- ficiency!" I was interested to see in the ward a case of Pick's disease, the pericardial pseudocirrhosis of the liver. The old question comes up here as to priority of description. In the special number of the Wiener klinische Wochenschrift, issued for the congress, Professor von Neusser describes it as "Morbus Bamberger." He states that in 1872 Bamberger described the condition as a special malady which he had already known for a long time and which up to that time had not been recognized in the literature. Certainly Pick deserves credit for having brought together all the known facts relating to a clinical condition to which very little attention had been given before his paper. I had a most interesting talk with Pick and Braner and Wenckebach on the whole question, which is not one simply of pericardial adhesion. Wenckebach has helped to solve the problem in a recent number of Volkman's Vorträge 
in an article on the "Relation Between Respiration and Circulation." Brauler of Marburg, who is coming over to the session of the American Medical Association, will discuss the sulject in connection with his operation of cardiolysis.

If anyone interested in hospitals-in every possible detail, construction, situation, general arrangements for the comfort of the patients, for the convenience of the students, for the advancement of science-if such an one wishes to have a Queen-of-Sheba sensation, let him visit the first group of the new buildings of the Allegemeines Krankenhaus. They have begun the rebuilding with the departments for women, and two of the three elinies, for midwifery and gynecology, are completed, one for Professor Schauta and the other for Professor Rosthorn, recently called from Heidelberg. About 10,000 diveries a year take place in the three clinics, one of which is for midwives. The new clinics are-exact düplicates of each other, and each has accommodation for about 200 patients. The buildings are of four stories, a central building with wings, built of brick and stucco, with spacious corridors, large windows, tiled floors and white oil-finished walls. Inside and out they form the most attractive hospital buildings that $I$ have ever seen. But it is not so much this aspect that gives one that sinking of the heart of which the Queen of Sheba complained when Solomon showed his treasures-it is the organization and the completeness of the arrangements for teaching and for the scientific study of disease. One large floor is assigned to students, who all live in the building while attending the midwifery cases. Each clinic has its own laboratory, a special museum for teaching purposes, a library and a fully equipped small laboratory adjoining the gynecologic operating room, so that an opinion may be given immediately as to the nature of a growth. Down to the smallest detail every care has been taken to make these two clinics the most perfect of their kind, and if the hospital is completed on this elaborate plan it will, indeed, be worthy of the fame of the Vienna school and there will be nothing like it in Europe or America. The government foots the bills, and the total cost of the two buildings has been $9,000,000$ kronen $(\$ 1,800,000)$

Professor Schlesinger very kindly took us to the Franz Josef Hospital, also a new building, on a less elaborate scale but very complete in all its appointments. It is particularly well arranged for the acute infectious diseases, and the most elaborate precautions are taken to isolate and disinfect the patients. Professor Schlesinger is very popular with American students, and we found working in his wards Dr. George Cheyne Shattuck III. of Boston, and young Dr. Fischel of St. Louis, both of whom have for some months been acting as voluntary assistants. It was interesting to see two wards devoted entirely to erysipelas; as far as possible all the cases in the city are semb connected with this hospital is a Areautiful new children's department, built by Professor Sellesinger's father-in-law. It looked to be an admirable model for the new Harriet Lane Johnston's children's department at the Johns Hopkins Hospital. In the arrangement for isolating cases, in the simple and easily worked character of the wards; in the laboratory arrangements and in the special incubators for feeble babies the hospital seemed much in advance of anything $I$ had ever seen.

The scientific laboratories of the medical school have been completely transformed. Dr. Fröhlich took us through Professor Meyer's Pharmacologic Institute and through the new physiologic laboratory and the anatomic department-such a contrast to the old days!

\section{CRITICISM OF WORK OF CONGRESS.}

The general impression one gets of the work of the congress is very favorable. Too much, perhaps, is attempted. There are too many papers, but the keenness of the men and the scientific interest are most stimulating. As I remarked about the congress two years ago in Munich, there is a strong tendency in internal medicine to-day toward physiologic and ehemical problems. On the long list of papers, eighty-eight in number, there were only about five dealing with bacteriologic questions. An extraordinary number dealt with ques- tions in physiologic pathology and presented the results of experimental work.

\section{INFLUENCE OF VIENNA ON AMERICAN MEDICINE.}

As a medical center Vienna has had a remarkable career and her influence, particularly on American medicine, has been very great. What was known as the first Vienna school in the eighteenth century was realy a transference by van Swieten of the school of Boerhaave from Leyden. The new Vienna school, which we know, dates from Rokitansky and Skoda, who really made Vienna the successor of the great Paris school of the early days of the nineteenth century. But Vienna's influence on American medicine has not been so much through Skoda and Rokitansky as through the group of brilliant specialists-Hebra, Sigmund and Neumann in dermatology; Arlt and Jaeger in ophthalmology; Schnitzler and von Schrötter in laryngology; Gruber and Politzer in otology. These are the men who have been more than others responsible for the successful development of these specialties in the United States. Austria may well be proud of what Vienna's school has done for the world, and she still maintains a great reputation, though it can not be denied, I think, that the Esculapian center has moved from the Danube to the Spree. But this is what has happened in all ages. Minerva Medica has never had her chief temples in any one country for more than a generation or two. For a long period at the Renaissance she dwelt in northern Italy, and from all parts of the world flocked to Padua and to Bologna. Then for some reason of her own she went to Holland, where she set up her chief temple at Leyden with Boerhaave as her high priest., Uncertain for a time, she flitted here with Boerhaave's pupils, van Swieten and de Haen, and could she have come to terms about a temple, she doubtless would have stayed permanently in London, where she found in John Hunter a great high priest. In the first four decades of the nineteenth century she lived in France, where she built a glorious temple to which all flocked. Why she left Paris, who can say? but suddenly she appeared here, and Rokitansky and Skoda rebuilt for her the temple of the new Vienna school, but she did not stay long. She had never settled in northern Germany, for though she loves art and science she hates with a deadly hatred philosophy and all philosophical systems applied to her favorite study. Her stately Grecian shrines, her beautiful Alexandrian home, her noble Roman temples, were destroyed by philosophy. Not until she saw in Johannes Müller and in Rudolph Virchow true and loyal disciples did she move to Cermany, where she stays in spite of the tempting offers from France, from Italy, from England and from Austria.

In an interview most graciously granted to me, as a votary of long standing, she expressed herself very well satisfied with her present home, where she has much honor and is everywhere appreciated. I boldly suggested that it was perhaps time to think or crossing the Atlantic and setting up her temple in the new world for a generation or two. I spoke of the many advantages, of the absence of tradition-here she visibly weakened, as she has suffered so much from this poison-the greater freedom, the enthusiasm, and then I spoke of missionary work. At these words she turned on me sharply and said: "That is not for me. We gods have but one motto-those that honor us we honor. Give me the temples, give me the priests, give me the true worship, the old Hippocratic service of the art and of the science of ministering to man, and I will come. By the eternal law under which we gods live I would have to come. I did not wish to leave Paris, where I was so happy and where I was served so faithfully by Bichat, by Laennec and by Louis"-and tears filled her eyes and her voice trembled with emotion-" "but where the worshipers are the most devoted, not, mark you, where they are the most numerous; where the clouds of incense rise highest, there must my chief temple be, and to it from all quarters will the faithful flock. As it was in Greece, in Alexandria, in Rome, in northern Italy, in France, so it is now in Germany, and so it may be in the new world I long to see" Doubtless she will come, but not till the present crude organization of our medical clinics is changed, not until there is a fuller realization of internal medicine as a science as well as an art. 